\title{
The cave environment influencing the lipid profile and hepatic lipogenesis of the fish Ancistrus cryptophthalmus Reis, 1987 (Siluriformes: Loricariidae)
}

\author{
Valquíria Aparecida Alves Bastos ${ }^{1}$, Rodrigo Lopes Ferreira ${ }^{2}$, Daniel Cardoso de Carvalho ${ }^{3}$, \\ Marina Lages Pugedo ${ }^{3}$, and Luciana de Matos Alves Pinto ${ }^{1 *}$ \\ ${ }^{1}$ Universidade Federal de Lavras, Departamento de Química, Caixa Postal 3037, 37200-000, Lavras, MG, Brazil \\ ${ }^{2}$ Universidade Federal de Lavras, Departamento de Biologia, Caixa Postal 3037, 37200-000, Lavras, MG, Brazil \\ ${ }^{3}$ Pontificia Universidade Católica de Minas Gerais, Programa de Mestrado em Zoologia de Vertebrados. Belo Horizonte, MG, Brazil
}

\begin{abstract}
The metabolism of hypogean organisms is frequently molded by the cave environment traits, especially food scarcity. The aim of the present work was to evaluate the influence of such environment on lipid composition and hepatic lipogenesis in the fish Ancistrus cryptophthalmus. For this, the species was compared to an epigean population of the species. A greater accumulation of total lipids was observed in the cave-dwelling fish (18.36 $\mathrm{g} / 100 \mathrm{~g}$ tissue) compared to the surface fish (14.09 $\mathrm{g} / 100 \mathrm{~g}$ tissue). The muscle fatty acid profile also varied between the populations. Arachidonic acid was only detected in the epigean fish, while docosahexaenoic acid was present in the cave fish. In the lipid profile of Ancistrus cryptophthalmus there was a higher proportion of saturated fatty acids, followed by monounsaturated and polyunsaturated fatty acids; Ancistrus sp. showed a predominance of monounsaturated fatty acids. Significant differences were also observed in the activities of the hepatic enzymes glucose-6-phosphate dehydrogenase and malic enzyme. The activities of these two enzymes were greater in the epigean animals. The differences could be related to different food availability observed in the two environments. An ecotone zone was observed, located next to the entrance of the Lapa do Angélica cave (Goiás State, Brazil), where the fishes showed characteristics that were intermediate between those of hypogean fishes from deeper within the cave, and the epigean population. It could be concluded that the characteristics of the cave environment significantly influenced the composition of muscle fatty acids and lipogenesis in the hypogean fish Ancistrus cryptophthalmus.
\end{abstract}

Keywords: fish; cave; fatty acids; malic enzyme; glucose-6-phosphate dehydrogenase; metabolism Received 31 May 2012; Revised 21 August 2012; Accepted 27 September 2012

Citation: $\quad$ Bastos V.A.A., Lopes Ferreira R., Carvalho D.C., Pugedo M.L. and de Matos Alves Pinto L., 2012. The cave environment influencing the lipid profile and hepatic lipogenesis of the fish Ancistrus cryptophthalmus Reis, 1987 (Siluriformes: Loricariidae). International Journal of Speleology, 42 (1), 15-23. Tampa, FL (USA) ISSN 0392-6672 http://dx.doi.org/10.5038/1827-806X.42.1.3

\section{INTRODUCTION}

Fish are important components of subterranean aquatic communities, where they often are at the top of the food web. Globally, the number of known fish species is currently around 28,000, of which 299 can be found in the hypogean environment, with at least 164 showing some degree of troglomorphism (Romero \& Paulson, 2001; Romero, 2009; Proudlove, 2010).

Brazil possesses a rich subterranean ichthyofauna, with more than 25 fish species that present troglomorphism compared to the corresponding epigean species (Trajano \& Bichuette, 2010). Most of these troglobitic fishes belong to the Siluriformes, especially the Trychomicteridae family, although there are representatives of other families and also of other orders (such as the Characiformes and Gymnotiformes)
(Trajano \& Bichuette, 2010). Globally, there are some troglobitic armored catfishes that belong to the Loricariidae family (Ancistrus). There are two Brazilian fishes of this genus: Ancistrus cryptophthalmus, found in the State of Goiás, central Brazil (Sabino \& Trajano, 1997), and Ancistrus formoso, found in the State of Mato Grosso do Sul (Trajano \& Bichuette, 2010).

Although the diversity of hypogean fishes is fairly well known, there exists little information concerning the metabolism of these organisms. Nevertheless, it is believed that the animals are hypometabolic, and tend to develop elaborate mechanisms for both searching for food and improving the capacity for lipid storage (Wilkens, 2005; Salin et al., 2010).

Lipids are important components of the diets of many animals, and are an efficient source of both energy and the fatty acids that are essential for 
development. In ectothermic animals, such as fish, lipids act as structural components responsible for the maintenance of fluidity of the plasma membrane, as well as for the storage and supply of energy, and are therefore essential for basic physiological functions (Brown \& Murphy, 1995). An ability to synthesize a wide variety of fatty acids is essential for all living organisms.

In fish, biosynthesis of fatty acids occurs mainly in the liver, and proceeds by the successive addition of two carbon units, derived from the malonyl group, to the growing lipid chain (Nelson \& Cox, 2010). This process involves the action of specific enzymes such as glucose-6-phosphate dehydrogenase, which provides energy in the form of NADPH in the pentose phosphate pathway, and the malic enzyme, which is involved in the pyruvate/malate cycle (Wang et al., 2005).

In most fish species, the fatty acid profile and the activity of the enzymes concerned with lipogenesis are affected by the composition of the diet and the frequency of feeding (Visentainer et al., 2005; Wang et al., 2005; Visentainer et al., 2007). For this reason, subterranean environments, which tend to be strongly oligotrophic, can promote alterations such as diminution of metabolism in cave fish, and a tendency for greater storage of lipids (Wilkens, 2005).

The objective of this work was therefore to investigate the influence of the subterranean environment on the lipid profile and hepatic lipogenesis of the fish Ancistrus cryptophthalmus. This was achieved using comparisons with epigean fish that inhabited the external stretch of the same water channel present in the Lapa do Angélica cave (Goiás State, Brazil). In addition, the study sought to identify whether there were any differences between individuals of the hypogean fishes that inhabited zones closer to the cave entrance (where there was a greater supply of nutrients), and fish that were found deeper within the cave.

\section{Study region}

The São Domingos karst region is located in the Serra do Calcário, in the central-west Brazilian State of Goiás, where the predominant vegetation is that of the cerrado (Brazilian savannah). This area has a semihumid tropical climate, with a dry period that extends from April to September (Klink \& Machado, 2005). The region is known for its rich subterranean ichthyofauna, and 66 limestone caves have been recorded, amongst which is the Angélica cave in the Terra Ronca State Park (13 31' 22.2" S, 46 22' 55.5" W).

The Angélica cave is the fourth largest Brazilian cave in terms of extent, with 14,100 meters of mapped galleries, 8,000 meters of which contain large, fastflowing watercourses (Auler et al., 2001). The stream conduit has an average width of around 5 meters, and the water depth varies between 0.5 and 2 meters. In the dry season, the measured discharge of water at the mouth of the cave was $2.27 \mathrm{~m}^{3} / \mathrm{s}$ (Trajano \& Bichuette, 2007).

\section{Fish species studied}

The Ancistrus cryptophthalmus Reis, 1987 (Fig. 1A) is found in four caves in the São Domingos karst region (the Angélica, Bezerra, São Vicente, and Passa Três caves). They have poorly-developed ocular structures, reduced body pigmentation, detritivore feeding habits, and precocial lifestyles. These characteristics can be interpreted as being specialized adaptations to the subterranean environment (Secutti \& Trajano, 2009).

In addition to the hypogean populations, the same region harbors epigean populations of the genus Ancistrus, which include an unidentified species (Fig. 1B). These animals, which are morphologically distinct to the hypogean, have better developed ocular structures, and intense pigmentation (Reis et al., 2006).

The fish of the genus Ancistrus provide an excellent model for studies concerning the adaptive evolution of cave-dwelling groups, because there are relatively abundant populations of the animals inhabiting both hypogean and epigean environments in the same region (Trajano \& Bichuette, 2007).

\section{METHODS}

\section{Capture and transport}

Ten individuals of Ancistrus cryptophtalmus (hypogean) and Ancistrus sp. (epigean) were collected manually using a net, in May 2011. No consideration was given to differences between the animals in terms of physiological factors, age, size, weight, stage of maturity, or anatomical features, in order to obtain a sample that was more representative of the overall population. In addition, the fish were handled as little as possible to minimize situations of stress.

The hypogean fish were collected at two points within the Angélica cave. Five individuals were obtained near the entrance (site $\mathrm{P}$, located around 300 meter far from the entrance), and the remainder deeper within the cave, approximately 1000 meters from the entrance (site P2) (Fig. 2). Since fish of the species Ancistrus cryptophtalmus are highly sedentary and live their entire life in a stretch of water less than $100 \mathrm{~m}$ long, there was a low probability of movement of the animals between the two locations (Trajano \& Bichuette, 2007). The nontroglobitic fish were collected in the epigean stretch

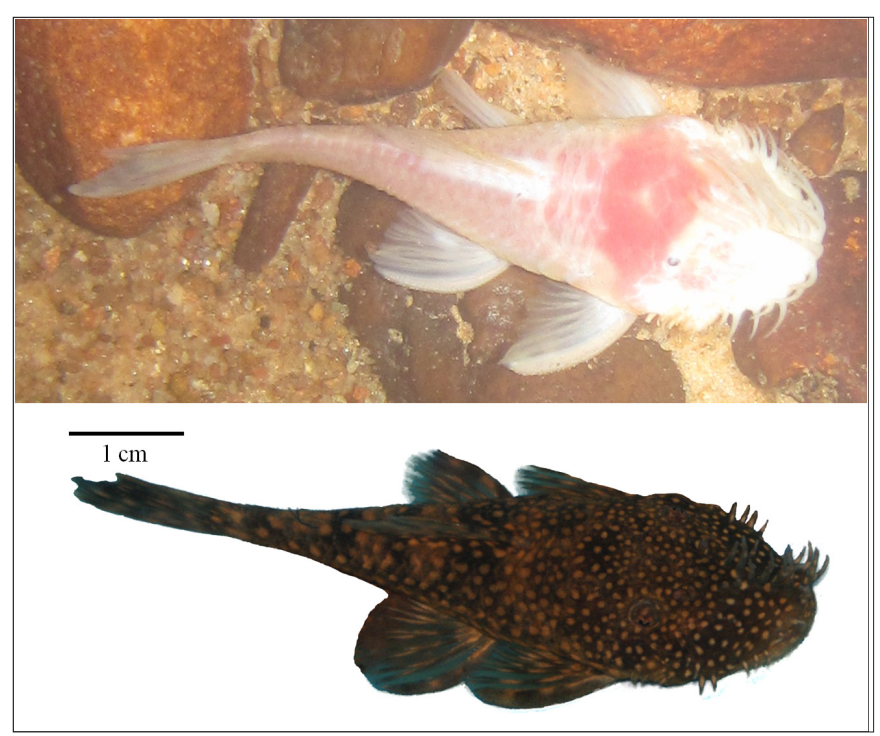

Fig. 1. Species of fish studied: A) Ancistrus cryptophthalmus; B) Ancistrus sp. 
of the Angélica River, at approximately 300 meters from the cave entrance.

Measurements of water $\mathrm{pH}$, temperature, and dissolved oxygen content were made in situ at the time of collection, using a multiprobe sensor (YSI). Samples of substrate were also collected from the riverbed at the three collection points, for later analysis of organic matter using the procedure described by Davies (1974).

The animals were transported to Universidade Federal de Lavras, in groups of five, in plastic containers (5 liter capacity) protected from light and with constant aeration. The containers were filled to the rim with water from the Angélica river in order to avoid impacts that could cause a situation of stress to the fish, according to the norms established by the Commission for Ethics in the Use of Animals of the Federal University of Lavras (license number: 002/11).

\section{Genetic analysis}

Samples of fins and muscle were obtained from 27 fishes representing four populations (22 from Angélica Cave: 5 specimens from a hypogean population inside the cave, 5 from a hypogean population near the surface and 11 from an epigean population outside the cave and described only as Ancistrus sp.). Five hypogean individuals from Passa-Três Cave were also analyzed. All tissues were stored in 95\% ethanol. DNA was isolated and 658 base pairs of the mitochondrial gene Cytochrome c Oxidase I (COI) amplified using the primers FishF1 and FishR1 (Ward et al., 2005) as described in Carvalho et al. (2011). Sequences were determined bi-directionally using the BigDye Terminator v3.1Cycle Sequencing Kit (Applied Biosystems, Inc.,Foster City, California, USA) following the manufacture's protocol on an Applied Biosystems Inc. 3130 Genetic Analyzer. Each recovered haplotype was deposited in GenBank (Accession numbers: JX477622-JX477648). One previously described Ancistrus brevipinnis COI sequence (Genbank number: EU359402.1) was also included in the analysis.

DNA sequences were analyzed using SeqScape v2.7 ${ }^{\circledR}$ software (Applied Biosystems, Inc., Foster City, California, USA). Genetic distances were estimated using Kimura's two-parameter (K2P) nucleotide substitution model (Kimura, 1980) using MEGA version 5.10 (Tamura et al., 2011).

\section{Biochemical analysis}

After transport, the animals were desensitized in an ice bath, weighed, and eviscerated, with separation of the liver for use in the enymatic analyses.

Samples of muscle tissue were submitted to lipid extraction and esterification using the method of Folch et al. (1957). The methyl esters of the fatty acids were determined using a Shimadzu GC-2010

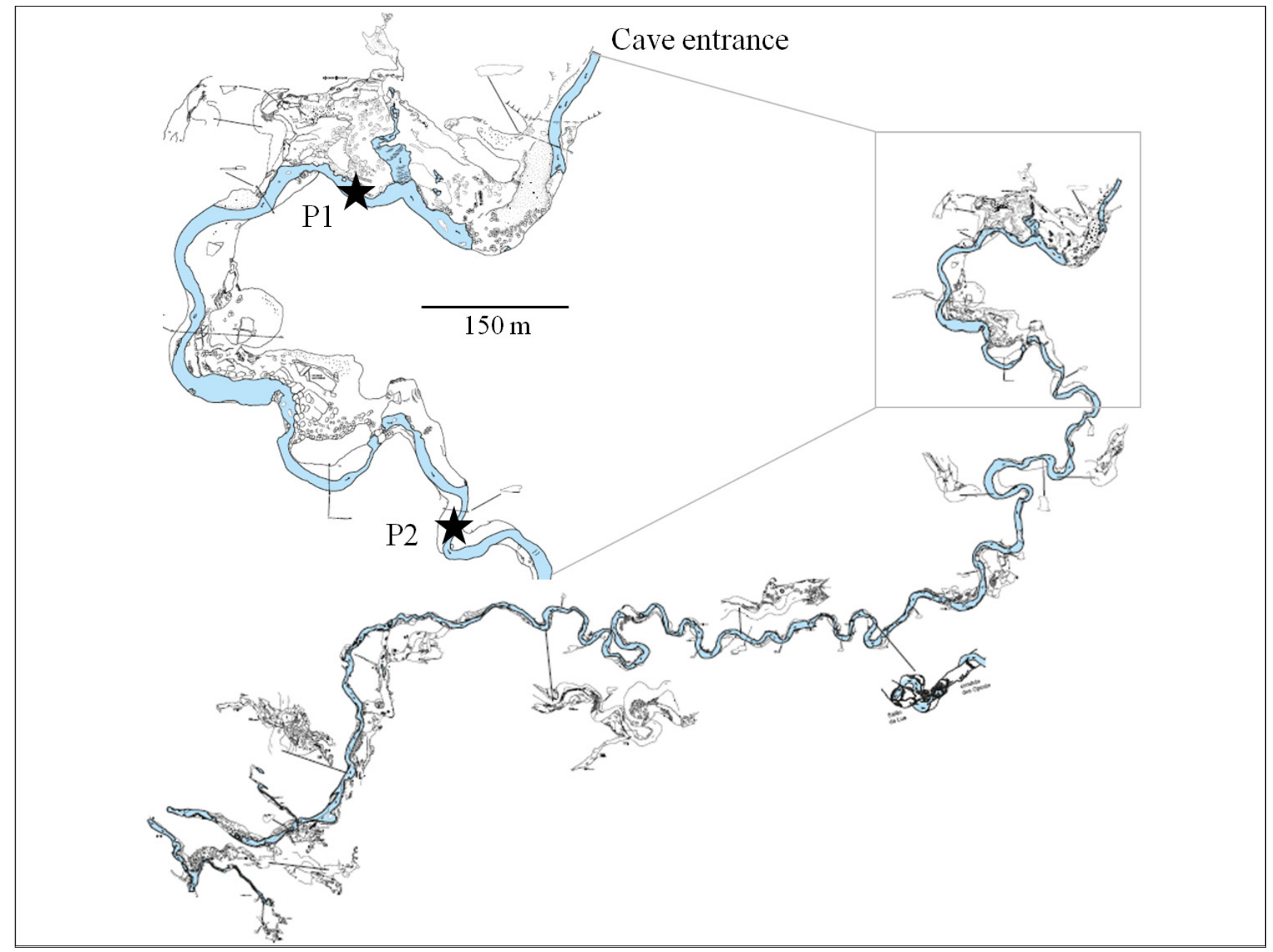

Fig. 2. Map of the Angélica Cave, indicating collection points $\mathrm{P} 1$ and $\mathrm{P} 2$. 
gas chromatograph equipped with a flame ionization detector and a DB-WAX fused silica capillary column (100 $\mathrm{m} \times 0.25 \mathrm{~mm})$. The operating conditions were as follows: splitless injection mode; $1 \mu \mathrm{L}$ injection volume; $260{ }^{\circ} \mathrm{C}$ detector temperature; $260{ }^{\circ} \mathrm{C}$ injector temperature; temperature program: $4^{\circ} \mathrm{C} \mathrm{min}^{-1}$ to 140 ${ }^{\circ} \mathrm{C}$, hold at $140{ }^{\circ} \mathrm{C}$ for 5 minutes, ramp at $4{ }^{\circ} \mathrm{C} \mathrm{min}^{-1}$ to $240{ }^{\circ} \mathrm{C}$, hold at $240{ }^{\circ} \mathrm{C}$ for 30 minutes.

The chromatographic peaks were identified by comparing retention times with those of a commercial standard (Supelco 37 Component FAME Mix, supplied by Sigma-Aldrich). The fatty acids were quantified by normalization of the peak areas, and the values were converted to percentages of the mass of muscle tissue, multiplying by the total lipid fraction content and by the conversion factor for fatty fish (0.9), as described by Holland et al. (1994).

The samples of liver tissue were homogenized in $25 \mathrm{mM}$ HEPES-KOH buffer at $\mathrm{pH} \mathrm{7.4,} \mathrm{centrifuged} \mathrm{at}$ $10,000 \mathrm{rpm}\left(4^{\circ} \mathrm{C}\right.$ for 30 minutes), and analyzed for the specific enzymatic activities of glucose-6-phosphate dehydrogenase and malic enzyme, according to the methods of Graeve (1994) and Spina et al. (1966), respectively. The enzyme kinetics was monitored using UV spectrophotometry (Shimadzu UV-1800). The total soluble protein contents of the livers were determined using the method described by Bradford (1976).

All the results were tested statistically using analysis of variance (ANOVA) and Tukey's test to identify significant differences among the sample mean values. The software used was R (R Development Core Team, 2011), and the significance level employed was 5\%.

\section{RESULTS}

At the time of sample collection, the river water at the epigean site presented a temperature of $24.8^{\circ} \mathrm{C}$, a dissolved oxygen content of $94.7 \%$, and a $\mathrm{pH}$ of 6.3. Inside the cave, where there was no significant difference between the conditions at the two collection points, the temperature was higher $\left(25.3{ }^{\circ} \mathrm{C}\right)$, and the dissolved oxygen content was lower (91.5\%). The water $\mathrm{pH}$ was the same at the hypogean and epigean sites. Physico-chemical information concerning the collection points is important because the conditions can significantly influence the metabolism of the fish.

The organic matter content of the sedimented substrate differed substantially between the two environments, with values of 1.84 and $0.38 \mathrm{~g} / \mathrm{cm}^{2}$ obtained at the epigean site and hypogean site P1 (closer to the cave entrance), respectively. The organic matter content was below the detection limit at the second hypogean site (deeper within the cave).

After trimming unclear ends, a total of 556 base pairs (bp) were obtained from each specimen. Three haplotypes were recovered from all samples analyzed, with a K2P genetic divergence ranging from 0 to $0,2 \%$. When comparing fishes collected only at Angélica Cave ( 5 individuals from a hypogean population inside the cave, 5 from a hypogean population near the surface and 11 from an epigian population) only one haplotype was recovered and no genetic divergence was observed between populations. At Passa-Três
Cave, two polymorphic sites were recovered in two specimens, resulting in a divergence of $0.2 \%$ between haplotypes. When comparing Ancistrus $s p$ and Ancistrus cryptophthalmus with Ancistrus brevipinnis a divergence of $6.9-7.2 \%$ was recovered.

The Ancistrus cryptophthalmus fish presented higher body weights, with values of between 2.09 and $2.17 \mathrm{~g}$, and greater deposition of lipids in the muscle tissue (17.6-18.36\%), compared to the epigean population whose average weight and muscle total lipid content were $1.21 \mathrm{~g}$ and $14.09 \%$, respectively (Fig. 3).

The lipid profiles revealed the presence of 14 fatty acids in the Ancistrus cryptophthalmus individuals collected at site $\mathrm{P} 1$, and 10 in fish of the same species collected at site P2. The lipid profile of the epigean Ancistrus sp. revealed the presence of 19 fatty acids (Table 1). Amongst those fatty acids identified in both species, the most prevalent were myristoleic (C14:1),

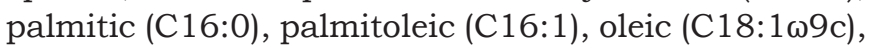

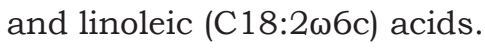

Significant differences between the hypogean and epigean fishes were observed in the proportions of saturated and monounsaturated fatty acids. While the cave fish from both sites within the cave showed high levels of saturated fatty acids $(62.88 \%$ for $\mathrm{P} 1$, and $62.75 \%$ for P2), and smaller proportions of monounsaturated fatty acids (24.54\% for P1, and $24.76 \%$ for P2), the epigean fish showed a higher content of monounsaturated (46.86\%) than saturated $(39.22 \%)$ fatty acids.

The total content of polyunsaturated fatty acids showed no significant difference between the populations, with the omega- 6 series predominant over the omega- 3 series in both cases.

In the analysis of the rates of lipogenesis, it was found that the specific activities of the hepatic enzymes (glucose-6-phosphate dehydrogenase and malic enzyme) differed significantly $(\mathrm{P}<0.05)$ between the hypogean and epigean fishes (Table 2). Higher specific enzyme activities in the epigean fish were indicative of greater lipogenesis in this population.

\section{DISCUSSION}

Studies of metabolism are essential for understanding the basic needs of animals, and were used here to elucidate the habits of the

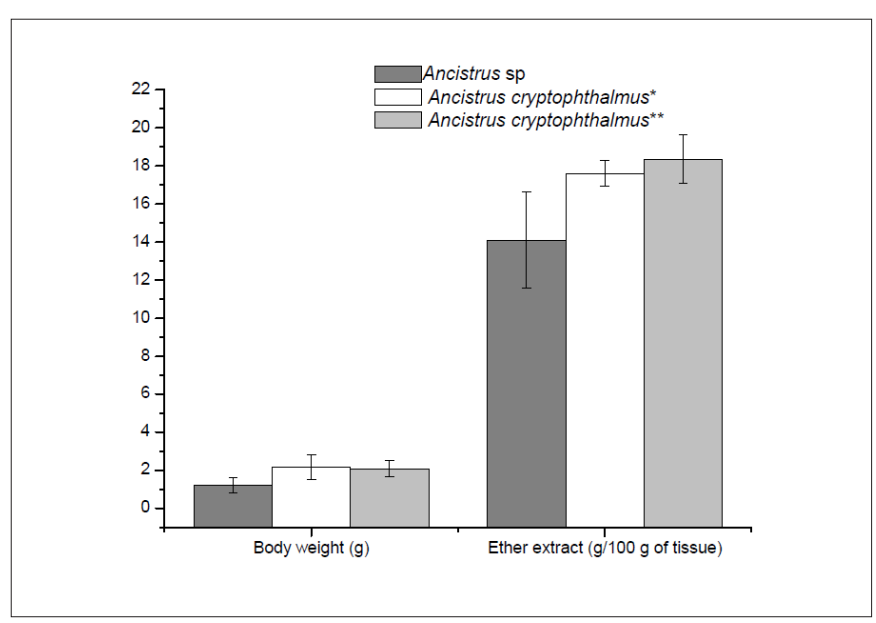

Fig. 3. Body weights and ether extract amounts of the epigean and troglobitic fish.

* Collected at site P1.

** Collected at site P2. 
Table 1. Fatty acid profiles of the species Ancistrus cryptophthalmus and Ancistrus sp.

Values are shown as means \pm standard deviation. Where the values expressed in $\%$ (on the same line) are followed by identical letters, differences between the values were not significant $(p>0.05)$. Where the values expressed in $\mathrm{g} / 100 \mathrm{~g}$ (on the same line) are followed by identical Greek letters, differences between the values were not significant ( $p>0.05)$. Differences were evaluated using analysis of variance (ANOVA) and Tukey's test. nd $=$ not determined.

\begin{tabular}{|c|c|c|c|c|c|c|}
\hline \multirow{2}{*}{ Fatty acid } & \multicolumn{2}{|c|}{ Ancistrus sp. } & \multicolumn{2}{|c|}{ Ancistrus cryp. ${ }^{*}$} & \multicolumn{2}{|c|}{ Ancistrus cryp. ${ }^{* *}$} \\
\hline & $\%$ & $\mathrm{~g} / 100 \mathrm{~g}$ & $\%$ & $\mathrm{~g} / 100 \mathrm{~g}$ & $\%$ & $g / 100 g$ \\
\hline C14:0 & $0.81 \pm 0.10 \mathrm{~b}$ & $0.10 \pm 0.01 \beta$ & $5.01 \pm 0.61 \mathrm{a}$ & $0.85 \pm 0.10 \alpha$ & $5.93 \pm 1.59 a$ & $0.96 \pm 0.25 \alpha$ \\
\hline C14:1 & $13.78 \pm 1.73 a$ & $1.79 \pm 0.22 \alpha$ & nd & nd & $14.22 \pm 3.06 a$ & $2.27 \pm 0.50 a$ \\
\hline C15:0 & $0.80 \pm 0.08 c$ & $0.10 \pm 0.01 \gamma$ & $4.58 \pm 0.70 \mathrm{a}$ & $0.77 \pm 0.11 \alpha$ & $3.35 \pm 0.25 b$ & $0.53 \pm 0.04 b$ \\
\hline C $15: 1$ & $0.94 \pm 0.15 b$ & $0.12 \pm 0.01 \beta$ & $4.89 \pm 0.56 a$ & $0.82 \pm 0.09 \alpha$ & nd & nd \\
\hline C16:0 & $25.67 \pm 1.66 \mathrm{~b}$ & $3.30 \pm 0.21 \beta$ & $48.82 \pm 1.01 \mathrm{a}$ & $8.18 \pm 0.19 \alpha$ & $49.54 \pm 5.69 a$ & $7.78 \pm 0.88 \alpha$ \\
\hline C16:1 & $11.36 \pm 0.40 \mathrm{a}$ & $1.45 \pm 0.05 \alpha$ & $1.88 \pm 0.91 \mathrm{~b}$ & $0.31 \pm 0.15 \beta$ & $10.54 \pm 2.60 a$ & $1.64 \pm 0.40 \alpha$ \\
\hline C17:0 & $0.46 \pm 0.10 \mathrm{c}$ & $0.06 \pm 0.01 \gamma$ & $3.50 \pm 0.61 a$ & $0.58 \pm 0.10 \alpha$ & $1.55 \pm 0.35 b$ & $0.24 \pm 0.05 \beta$ \\
\hline C17:1 & $0.81 \pm 0.15 b$ & $0.10 \pm 0.01 \beta$ & $2.41 \pm 0.45 a$ & $0.39 \pm 0.07 \alpha$ & nd & nd \\
\hline C18:0 & $8.06 \pm 0.52$ & $1.01 \pm 0.06$ & nd & nd & nd & nd \\
\hline C18:1w9c & $19.40 \pm 0.56 a$ & $2.43 \pm 0.07 \alpha$ & $11.42 \pm 0.65 b$ & $1.86 \pm 0.10 \beta$ & nd & nd \\
\hline C18:2w6t & $1.69 \pm 0.34$ & $0.21 \pm 0.04$ & nd & nd & nd & nd \\
\hline C18:2w6c & $7.07 \pm 0.60 \mathrm{a}$ & $0.88 \pm 0.07 \alpha$ & $5.61 \pm 1.155 \mathrm{a}$ & $0.91 \pm 0.18 \alpha$ & $7.01 \pm 1.48 \mathrm{a}$ & $1.06 \pm 0.22 \alpha$ \\
\hline C20:0 & $2.77 \pm 0.21 \mathrm{a}$ & $0.34 \pm 0.02 \alpha$ & $0.95 \pm 0.24 b$ & $0.15 \pm 0.03 \beta$ & $2.35 \pm 0.31 \mathrm{a}$ & $0.35 \pm 0.04 \alpha$ \\
\hline C18:3w6 & $0.51 \pm 0.36 \mathrm{~b}$ & $0.19 \pm 0.04 \alpha$ & $0.95 \pm 0.41 \mathrm{a}$ & $0.21 \pm 0.06 \alpha$ & $1.09 \pm 0.34 a$ & $0.16 \pm 0.05 \alpha$ \\
\hline C20:1 & $0.51 \pm 0.004$ & $0.06 \pm 0.004$ & nd & nd & nd & nd \\
\hline C22:0 & $0.63 \pm 0.13$ & $0.07 \pm 0.01$ & nd & nd & nd & nd \\
\hline $\mathrm{C} 20: 3 \omega 6$ & $1.98 \pm 0.32$ & $0.24 \pm 0.03$ & nd & nd & nd & nd \\
\hline C20:4w6 & $0.38 \pm 0.007$ & $0.04 \pm 0.008$ & nd & nd & nd & nd \\
\hline C22:2 & nd & nd & $0.78 \pm 0.11$ & $0.13 \pm 0.09$ & nd & nd \\
\hline $\mathrm{C} 24: 1$ & nd & nd & $3.92 \pm 0.75$ & $0.56 \pm 0.10$ & nd & nd \\
\hline $\mathrm{C} 22: 6 \omega 3$ & $1.18 \pm 0.20 \mathrm{~b}$ & $0.14 \pm 0.02 \beta$ & $4.85 \pm 0.66 a$ & $0.74 \pm 0.10 \alpha$ & $4.36 \pm 0.95 a$ & $0.63 \pm 0.13 \alpha$ \\
\hline$\Sigma$ Saturates & $39.22 \pm 1.98 \mathrm{~b}$ & $5.00 \pm 0.25 \beta$ & $62.88 \pm 1.07 a$ & $10.55 \pm 0.18 \alpha$ & $62.75 \pm 6.54 a$ & $9.86 \pm 1.02 \alpha$ \\
\hline$\sum$ Monounsaturates & $46.83 \pm 1.47 a$ & $5.96 \pm 0.19 \alpha$ & $24.54 \pm 1.24 b$ & $3.96 \pm 0.20 \beta$ & $24.76 \pm 5.06 \mathrm{~b}$ & $3.90 \pm 0.81 \beta$ \\
\hline$\sum$ Polyunsaturates & $13.94 \pm 1.10 \mathrm{a}$ & $1.71 \pm 0.13 \alpha$ & $12.56 \pm 0.48 \mathrm{a}$ & $2.00 \pm 0.07 \alpha$ & $12.47 \pm 2.14 a$ & $1.86 \pm 0.31 \alpha$ \\
\hline$\sum \omega 3$ & $1.18 \pm 0.20 \mathrm{~b}$ & $0.14 \pm 0.02 \beta$ & $4.85 \pm 0.66 a$ & $0.74 \pm 0.10 \alpha$ & $4.36 \pm 0.95 a$ & $0.63 \pm 0.13 \alpha$ \\
\hline$\sum \omega 6$ & $12.75 \pm 1.14 a$ & $1.57 \pm 0.14 \alpha$ & $6.94 \pm 1.12 b$ & $1.12 \pm 0.18 \beta$ & $8.10 \pm 1.80 \mathrm{~b}$ & $1.22 \pm 0.26 \beta$ \\
\hline
\end{tabular}

* Collected at site P1.

** Collected at site P2.

cave fish. The hypogean environment is unusual when compared to epigean environments, since there is no photoperiod and food availability is low. For many animals, these factors preclude the establishment of viable populations in subterranean ecosystems (Culver et al., 2009). A fish species would become actually established in the hypogean environment, if it develop morphological, physiological, metabolic, and behavioral specializations (Mathieu \& Hervant, 2006; Reis et al., 2006).

In a study of the epigean fish species Micropterus salmoides, it was shown that when subjected to periods of fasting, the animals developed the capacity to store proteins and lipids as a means of guaranteeing a supply of energy (Cyrino et al., 2000). This ability to store nutrients, developed by various fish species as a result of fasting (Salin et al., 2010), provides a basis for an understanding of the results obtained in the present work. The hipogean fishes presented a higher weight and greater lipid deposition in the muscle tissue than the epigean Ancistrus sp., which is provided with a greater quantity of organic matter in its habitat.

A large sinkhole at the entrance to the Angélica cave enables transport of quantities of organic matter, mainly leaves and small invertebrates, into the cave interior. However, fish of the Ancistrus genus are essentially grazers, so that even given the transfer of such organic matter, the amount of food available to these fish is considerably smaller in the cave habitat, and consists only of a film of fine particulate organic matter (Power, 1990; Trajano \& Bichuette, 2007).

It is recognized that a reduction in the availability of food is generally associated with a worsening of the 
Table 2. Specific activities of glucose-6-phosphate dehydrogenase and the malic enzyme in epigean and hypogean fish.

Values are shown as means \pm standard deviation. Where the values on the same line are followed by identical letters, differences between the values were not significant $(p>0.05)$. Differences were evaluated using analysis of variance (ANOVA) and Tukey's test.

\begin{tabular}{|l|l|l|l|}
\hline Enzyme & $\begin{array}{l}\text { Ancistrus sp. } \\
\text { (U/mg of ptn) }\end{array}$ & $\begin{array}{l}\text { Ancistrus cryp. } \\
\text { (U/mg of ptn) }\end{array}$ & $\begin{array}{l}\text { Ancistrus cryp.* } \\
\text { (U/mg of ptn) }\end{array}$ \\
\hline $\begin{array}{l}\text { Glucose-6-phosphate } \\
\text { dehydrogenase }\end{array}$ & $0.633 \pm 0.116 \mathrm{a}$ & $0.271 \pm 0.097 \mathrm{~b}$ & $0.189 \pm 0.098 \mathrm{~b}$ \\
\hline Malic & $0.048 \pm 0.011 \mathrm{a}$ & $0.034 \pm 0.006 \mathrm{a}$ & $0.013 \pm 0.011 \mathrm{~b}$ \\
\hline
\end{tabular}

* Collected at site P1.

** Collected at site P2.

condition of fish (Oscoz et al., 2005). Nonetheless, metabolic changes, such as greater deposition of body fat, occur in order to maintain a constant nutritional status and bodily condition, even in an environment with limited resources, such as a cave.

Although the total lipid contents of the muscle tissues of the Ancistrus cryptophthalmus fish were higher, the variety of fatty acids in the lipid profile was smaller than observed in the epigean population. Several studies have shown that the profile of fatty acids found in the muscle tissues of fish reflects the variability of these compounds in the diets of the animals (Visentainer et al., 2005; Vieira et al., 2011). Valente et al. (2007) found that in the fish species Dicentrarchus labrax, the provision of linoleic acid in the diet was directly reflected in the muscle content of this fatty acid as well as its derivatives formed during the processes of elongation and desaturation. The findings of the earlier studies were corroborated by the results obtained in the present work, where the hypogean fish that had a more restricted diet (in an habitat poor in organic matter) exhibited a reduced range of fatty acids in their muscle tissues, compared to the epigean organisms.

Regions close to the entrances of caves often show structural, biological, and physical gradients, creating a zone of transition between the epigean and hypogean systems. Such regions can be considered as ecotones, with distinct characteristics due to the equilibrium established between the epigean zone, where resources are readily available, and the hypogean zone, where the environment is more stable (Prous et al., 2004).

Due to the existence of an ecotone zone located close to site P1, the hypogean fishes collected at this area presented a range of fatty acids that was intermediate between those of the epigean fish and the animals collected at the site deeper within the cave. It is therefore possible that the diet of the fish from site $\mathrm{P} 1$ was richer and more diversified than that of fish from deeper regions of the cave, but less rich than that of their epigean population. Even though the sample population was small (5 fish at each collection point), the information presented is representative of the total population of Ancistrus cryptophthalmus in the Angélica cave, since it employed data that were biochemical in nature, rather than morphological measurements alone.
The elevated levels of palmitic (C16:0) and palmitoleic (C16:1) acids in both of the population studied, and the lower levels of long chain fatty acids (C20 and C22), are common characteristics of freshwater fish (Çelik et al., 2005; Inhamuns et al., 2009). On the other hand, stearic acid (C18:0), which is also common in the lipid profile of freshwater fish, was not found in the hypogean fish Ancistrus cryptophthalmus. Since the fatty acid composition reflects the diet of the animal, it can therefore be inferred that the diet of the cavedwelling fish was probably deficient in this fatty acid (Inhamuns et al., 2009).

Eicosenoic (C20:1), behenic (C22:0), eicosatrienoic

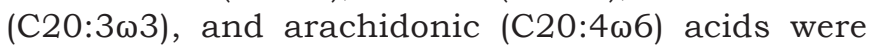
only detected in the epigean fish. Arachidonic acid

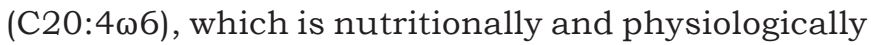
important for fish, is synthesized from the essential

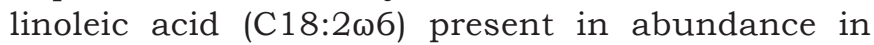
cave-dwelling fish (Martino, 2003). The absence of arachidonic acid in individuals of the Ancistrus cryptophthalmus is suggestive of a deficiency in the specific desaturases and elongases responsible for catalyzing the conversion of linoleic acid into longer chain derivatives (such as arachidonic acid).

It should also be noted that conditions of stress, of any nature, predispose fish to various illnesses. Hence, in an environment where conditions are adverse, such as that of a cave, compared to epigean environments a fraction of the polyunsaturated fatty acids that are synthesized is directed to the immunological system in order to maintain it active, which could explain the low availability of these compounds in the muscle tissues of Ancistrus cryptophthalmus (Sargent et al., 1999).

In fish, the balance between saturated and unsaturated fatty acids is intimately related to maintenance of the fluidity of the cell membranes, and is greatly influenced by temperature (Ribeiro et al., 2011). Generally, a decrease in temperature results in an increase in the degree of unsaturation, since unsaturates are required in the membrane phospholipids to maintain flexibility and permeability (Lovell, 1991). Conversely, in higher temperature aquatic environments, it is often the saturated fatty acids that predominate in the lipid profiles (Visentainer et al., 2007).

This is supported by the present findings, where Ancistrus cryptophthalmus showed higher levels of saturated fatty acids, while monounsaturates predominated in the epigean fishes, since during the collection period, which took place on a sunny day in the dry season, the hypogean site on the Angélica river was $0.5^{\circ} \mathrm{C}$ warmer than the epigean site.

Meanwhile, it is important to note that according to Secutti \& Trajano (2009) there is a diurnal temperature cycle in the Angélica cave, within a range of around $22.5{ }^{\circ} \mathrm{C}$ to $25^{\circ} \mathrm{C}$, and that seasonal changes in climate can affect the lipid profile of fish (Inhamuns et al., 2009; Kalyoncu et al., 2009). Further work over a more extended period will be needed to fully investigate these effects.

As observed for Ancistrus cryptophthalmus, other studies of freshwater fish have also shown that when 
the proportion of saturated fatty acids in the muscle tissues increases, the level of polyunsaturated fatty acids decreases (Inhamuns et al., 2009).

In addition to Ancistrus sp., other fish that are not cave-dwellers, such as cachara (Pseudoplatystoma fasciatum), pintado (Pseudoplatystoma corruscans), pacu (Piaractus brachypomus), and dourado (Salminus brasiliensis) present higher concentrations of monounsaturated fatty acids in their muscle tissues (Ramos Filho et al., 2008; Sharma et al., 2010).

Considering the polyunsaturated fatty acids, Gutierrez \& Silva (1993) reported that the great majority of freshwater fish caught in Brazil are deficient in the omega-3 series fatty acids, such as eicosapentaenoic acid (C20:5 33$)$ and docosahexaenoic acid (C22:6 33$)$. These two compounds are produced endogenously from a-linolenic acid, found in large quantities in marine plants.

Eicosapentaenoic acid (C20:5w3) was not detected in either Ancistrus cryptophthalmus or Ancistrus sp.,

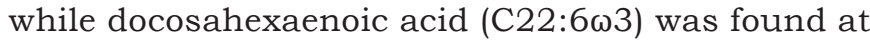
higher concentrations in the troglobitic fish.

According to Sargent et al. (1999), docosahexaenoic

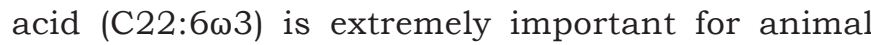
development, and can be found at high levels in neural tissues as well as the ocular apparatus of fish. Since the ocular structure of Ancistrus cryptophthalmus is less developed than that of the corresponding epigean organisms, there is greater availability of this fatty acid in the muscle tissue.

The greater part of lipid synthesis occurs in the hepatic tissue of fish (Figueiredo-Silva et al., 2005; Valente et al., 2007). In most animals, the pentose phosphate pathway, catalyzed by the glucose-6phosphate dehydrogenase enzyme, is the principle source of NADPH (up to 60\%) for the synthesis of fatty acids. The malic enzyme, important in the pyruvate/malate cycle, provides an alternative route that can also contribute to the supply of NADPH. The contribution of each of these enzymes depends, amongst other factors, on the species and the conditions to which the fish are subjected (Wang, 2005).

The specific enzyme activity values obtained here for both fish populations are in agreement with data reported in the literature, according to which specific activity values for fish lie in the ranges $0.109-0.920 \mathrm{U} / \mathrm{mg}$ of protein for glucose-6phosphate dehydrogenase, and 0.013-0.082 U/mg of protein for the malic enzyme (Borba et al., 2003; Valente et al., 2007).

It has been reported that the activities of the enzymes that participate in the processes of lipogenesis and lipid storage in fish (such as glucose-6-phosphate dehydrogenase and the malic enzyme) are affected by the composition of the diet of the animal (Valente et al., 2007). Studies have shown that in many species of fish lipogenesis is stimulated by diets rich in carbohydrates (Dias et al., 2004), and is suppressed when the diet contains a high lipid content (Catacutan \& Coloso, 1997; Wang et al., 2005).
The specific activities of the two enzymes investigated were lower in the Ancistrus cryptophthalmus collected at site P2, compared to the epigean population, which could have been due to a scarcity of food in the cave environment (Catacutan \& Coloso, 1997; Dias et al., 2004).

In the case of the malic enzyme, the specific activities were the same for Ancistrus cryptophthalmus collected at site P1 and the Ancistrus sp.. Site P1 was located close to the entrance of the Angélica cave, in an area that could be characterized as a transition zone, and where the concentration of organic matter in the sedimented material was intermediate between the concentrations measured at site P2 and the epigean site. Hence, the hypogean fish found in this region of the cave retained the principal route for production of NADPH (the pentose phosphate pathway), while at the same time the greater availability of food induced higher activity of the malic enzyme in the alternative route.

The mtDNA COI region could correctly differentiate Ancistrus brevipinnis from Ancistrus sp and $A$. cryptophthalmus, but could not differentiate the epigean species Ancistrus sp from the hypogean species A. cryptophthalmus. The lack of genetic divergence observed between Ancistrus sp and A. cryptophthalmus is strong evidence that both morphotypes correspond to the same species. Phenotypic plasticity and gene flow between epigean and hypogean populations are possible hypotheses that should be tested in order to explain the contradiction between morphological and molecular data.

The most remarkable ecological characteristics presented by hypogean fish populations are their small size, restricted geographical distribution, vulnerability to environmental disturbances and sensitivity to stress (Bichuette \& Trajano, 2008). Due to the fragility of these populations, it is very important to elucidate the metabolism of cave fishes in order to understand their habits and create favorable conditions for their preservation.

\section{CONCLUSIONS}

It is concluded that the characteristics of the cave environment, especially the quantity of available food, had a significant influence on the composition of fatty acids in the muscles, as well as on lipogenesis, in the fish Ancistrus cryptophthalmus, which contributed to differences between the hypogean and epigean populations.

The existence of an ecotone zone was observed close to the entrance of the Angélica cave, where the characteristics of the fish were intermediate between those of hypogean and epigean populations.

Since Ancistrus cryptophthalmus and Ancistrus sp. (undescribed and non-troglomorphic species) comprise the same species (as shown by the genetic analysis), we cannot consider $A$. cryptophtalmus as a troglobitic species, but as a troglophilic species with troglomorphic populations. 
ACKNOWLEDGEMENTS

The authors are grateful to CNPq (Conselho Nacional de Desenvolvimento Científico e Tecnológico) for financial support, to IBAMA (Instituto Brasileiro do Meio Ambiente e dos Recursos Naturais Renováveis) for licenses $n^{\circ}$ 23907-1 and $n^{\circ}$ 13295-2, and to SEMARH (Secretaria do Meio Ambiente e dos Recursos Hídricos de Goiás) for license no. 010/2011. Thanks are also due to Francisco Alexandre Costa Sampaio and Matheus Henrique Simões for assistance in field collections; to Regina Beatriz and Arnor for hospitality in the Terra Ronca State Park; and to Grupo Bambui de Pesquisas Espeleológicas for providing the map of the Angélica cave. RLF also thank Conselho Nacional do Desenvolvimento Científico e Tecnológico (CNPq grant 301061/2011-4).

\section{REFERENCES}

Auler A., Rubbioli E. \& Brandi. R., 2001- As grandes cavernas do Brasil. Grupo Bambui, Belo Horizonte, 228 p.

Bichuette M. E. \& Trajano E., 2008 - Ituglanis mambai, a new subterraneam catfish from a karst área of Central Brazil, rio Tocantins basin (Siluriformes: Trichomycteridae). Neotropical Ichthyology, 6: 9-15.

Borba M. R., Fracalossi D. M., Pezzato L. E., Menoyo D. \& Bautista J. M., 2003 - Growth, lipogenesis and body composition of piracanjuba (Brycon orbignyanus) fingerlings fed different dietary protein lipid concentrations. Aquatic Living Resources, 16: 362-369. http://dx.doi.org/10.1016/S0990-7440(03)00061-5

Bradford M. M., 1976 - A rapid sensitive method for quantitation of microgram quantities of protein utilizing the principle of protein-dye binding. Analytical Biochemistry, 72: 248-254. http://dx.doi.org/10.1016/0003-2697(76)90527-3

Brown M. L. \& Murphy B. R., 1995 - Effects of season, maturity, and sex on lipid lass dynamics in largemouth bass (Micropterus salmoides Lacepede). Ecology of Freshwater Fish, 4: 124-130. http://dx.doi.org/10.1111/j.1600-0633.1995.tb00125.x

Catacutan M. R. \& Coloso R. M., 1997 - Growth of juvenile Asian seabass, Lates calcarifer, fedvarying carbohydrate and lipid levels. Aquaculture, 149: 137-144. http://dx.doi.org/10.1016/S0044-8486(96)01432-9

Carvalho D. C., Oliveira D. A. A., Pompeu P. S., Leal C. G., Oliveira C. \& Hanner R., 2011 - Deep barcode divergence in Brazilian freshwater fishes: the case of the São Francisco River basin. Mitochondrial DNA, 22: 80-86.

Çelik M., Diler A. \& Küçükgülmez A., 2005 - A comparison of the proximate compositions and fatty acid profiles of zander (Sander lucoperca) from two different regions and climatic conditions. Food Chemistry, 92: 637-641. http://dx.doi.org/10.1016/j.foodchem.2004.08.026

Culver D. C., Pipan T. \& Schneider K., 2009 - Vicariance, dispersal and scale in the aquatic subterranean fauna of karst regions. Freshwater Biology, 54: 918-929. http://dx.doi.org/10.1111/j.1365-2427.2007.01856.x

Cyrino J. E. P., Portz L. \& Martino R. C., 2000 - Retenção de proteina e energia em juvenis de "black bass" Micropterus salmoides. Scientia Agrícola, 57: 609-616. http://dx.doi.org/10.1590/S0103-90162000000400003

Davies B. E., 1974 - Loss-on-ignition as an estimate of soil organic matter. Soil Science Society of America, 38: 347-353. http://dx.doi.org/10.2136/ sssaj1974.03615995003800010046x
Dias J., Rueda-Jasso R., Panserat S., Conceição L. E. C., Gomes E. F. \& Dinis M. T., 2004 - Effect of dietary carbohydrate-to-lipid ratios on growth, lipid deposition and metabolic hepatic enzymes in juvenile Senegalese sole (Solea senegalensis. Kaup). Aquaculture Research, 35: 1122-1130. http://dx.doi.org/10.1111/j.1365-2109.2004.01135.x

Figueiredo-Silva A. C., Rema P., Bandarra N. M., Nunes M. L. \& Valente L. M. P., 2005 - Effects of dietary conjugated linoleic acido in growth, nutrient utilization, body composition, and hepatic lipogenesis in rainbow trout juveniles (Oncorhynchus mykiss). Aquaculture, 248: 163-172. http://dx.doi.org/10.1016/j.aquaculture.2005.04.022

Folch J., Lees M. \& Stanley G. H. S., 1957 - Simple method for the isolation and purification of total lipids from animal tissues. Journal of Biological Chemistry, 226: 497-509.

Graeve K., 1994 - Purification, characterization and cDNA sequence of glucose -6-phosphate dehydrogenase from potato(Solanum tuberosum L.). PlantJournal, 5:353-361. http://dx.doi.org/10.1111/j.1365-313X.1994.00353.x

Gutierrez L. E. \& Silva R. C. M., 1993 - Fatty acid composition of commercially important fish from Brazil. Scientia Agricola, 50: 478-483. http:/ /dx.doi.org/10.1590/S0103-90161993000300023

Holland B., Welch A. A., Unwin I. D., Buss D. H., Paul A. A. \& Southgate D. A. T., 1994 - McCance and Widdowson's The Composition of Foods. RSC, Cambridge, $462 \mathrm{p}$.

Inhamuns A. J., Franco M. R. B. \& Batista W. S., 2009 - Seasonal variations in total fatty acid composition of muscles and eye sockets of tucunaré (Cichla sp.) from the Brazilian Amazon area. Food Chemistry, 117: 272-275. http://dx.doi.org/10.1016/j.foodchem.2009.03.113

Kalyoncu L., Kissal S. \& Aktumsek A., 2009 - Seasonal changes in the total fatty acid composition of Vimba, Vimba vimba tenella (Nordmann, 1840) in Egirdir Lake, Turkey. Food Chemistry, 116: 728-730. http:/ / dx.doi.org/10.1016/j.foodchem.2009.03.016

Kimura M., 1980 - A simple method for estimating evolutionary rates of base substitutions through comparative studies of nucleotide sequences. Journal of Molecular Evolution, 16: 111-120. http://dx.doi.org/10.1007/BF01731581

Klink C. A. \& Machado R. B., 2005 - Conservation of the Brazilian Cerrado. Conservation Biology, 19: 707-713. http://dx.doi.org/10.1111/j.1523-1739.2005.00702.x

Lovell R. T., 1991 - Nutririon of aquaculture species. Journal of Animal Science, 69: 4193-4200.

Mathieu J. \& Hervant F., 2006 - Adaptation: Physiological. In: Gunn J. (Ed.). Encyclopedia of Caves and Karst Science. New York: Taylor \& Francis: 23-25.

Nelson D. L. \& Cox M. M., 2010 - Lehninger principios de bioquímica. Sarvier, São Paulo, 1304 p.

Oscoz J., Campos F. \& Escala M. C., 2005 - Weightlength relationships of some fish species of the Iberian Peninsula. Journal of Applied Ichthyology, 21: 73-74. http://dx.doi.org/10.1111/j.1439-0426.2004.00587.x

Power M. E., 1990 - Enhancement by Indirect Effects of Grazers: Armored Catfish, Algae, and Sediment. Ecological Society of America, 71: 897-904.

Proudlove G. S., 2010 - Biodiversity and distribution of the subterranean fishes of world. In: Trajano E., Bichuette M. E. \& Kapoor B. G. (Eds.), Biology of Subterranean Fishes. Science Publishers, Enfield: 41-63.

Prous X., Ferreira R. L. \& Martins R. P., 2004 - Ecotone delimitation: Epigean-hypogean transition in cave ecosystems. Australian Ecology, 29: 374-382. http://dx.doi.org/10.1111/j.1442-9993.2004.01373.x 
$\mathrm{R}$ Development Core Team, 2011 - R: a language and environment for statistical computing. Vienna: $\mathrm{R}$ Foundation for Statistical Computing. Available at: http://www.R-project.org/. Accessed 10/12/2011.

Ramos Filho M. M., Ramos M. I. L., Hiane P. A. \& Souza E. M. T., 2008 - Perfil lipídico de quatro espécies de peixes da região pantaneira de Mato Grosso do Sul. Ciência e Tecnologia de Alimentos, 28: 361-365. http://dx.doi.org/10.1590/S0101-20612008000200014

Reis R. E., Trajano E., Hingst-Zaher E., 2006 - Shape variation in surface and cave populations of the armoured catfishes Ancistrus (Siluriformes: Loricariidae) from the São Domingos karst area, upper Tocantins River, Brazil. Journal of Fish Biology, 68: 414-429. http://dx.doi.org/10.1111/j.0022-1112.2006.00891.x

Ribeiro P. A. P., Rosa P. V., Vieira J. S., Gonçalves A. C. S. \& Freitas R. T. F., 2011 - Perfil lipídico e composição química de tilápias nilóticas em diferentes condições de cultivo. Revista Brasileira de Saúde Produção Animal, 12: 199-208.

Romero A., 2009 - Cave Biology: Life in Darkness. Cambridge University Press, New York, 215 p. http://dx.doi.org/10.1017/CBO9780511596841

Romero A. \& Paulson K. M., 2001 - It's a wonderful hypogean life: a guide to the troglomorphic fishes of the world. Environmental Biology of Fishes, 62: 13-41. http://dx.doi.org/10.1023/A:1011844404235

Sabino J. \& Trajano E., 1997 - A new species of blind armoured catfish, genus Ancistrus, from caves of Bodoquena region, Mato Grosso do Sul, southwestern Brazil (Siluriformes, Loricariidae, Ancistrinae). Revue Français d'Aquariologic, 24: 73-78.

Salin K., Voituron Y., Mourin J. \& Hervant F., 2010 - Cave colonization without fasting capacities: an example with the fish Astyanax fasciatus mexicanus. Comparative Biochemistry and Physiology Part A, 156: 451-457. http://dx.doi.org/10.1016/j.cbpa.2010.03.030

Sargent J., Bell G., McEvoy L., Tocher D. \& Estevez A., 1999 - Recent developments in the essential fatty acid nutrition of fish. Aquaculture, 177: 191-199. http://dx.doi.org/10.1016/S0044-8486(99)00083-6

Secutti S. \& Trajano E., 2009 - Reproductive behavior, development and eye regression in the cave armored catfish, Ancistrus cryptophthalmus Reis, 1987 (Siluriformes: Loricariidae), breed in laboratory. Neotropical Ichthyology, 7: 479-490. http://dx.doi.org/10.1590/S1679-62252009000300016

Sharma P., Kumar V., Sinha A. K., Ranjan J., Kithsiri H. M. P. \& Venkateshwarlu G., 2010 Comparative fatty acid profiles of wild and farmed tropical freshwater fish rohu (Labeo rohita). Fish Physiology Biochemistry, 36: 411-417. http://dx.doi.org/10.1007/s10695-009-9309-7

Spina J., Bright H. J. \& Rosenbloom J., 1966 - Purification and proprieties of L-malic enzyme from Escherichia coli. Biochemistry, 9: 29-39.
Tamura K., Peterson D., Peterson N., Stecher G., Nei M. \& Kumar S., 2011 - MEGA5: Molecular Evolutionary Genetics Analysis using Maximum Likelihood, Evolutionary Distance, and Maximum Parsimony Methods. Molecular Biology and Evolution, 28: 2731-2739. http://dx.doi.org/10.1093/molbev/msr121

Trajano E. \& Bichuette M. E., 2007 - Population ecology of cave armoured catfish, Ancistrus cryptophthalmus Reis 1987, from central Brazil (Siluriformes: Loricariidae). Ecology of Freshwater Fish, 16: 105-115. http://dx.doi.org/10.1111/j.1600-0633.2006.00196.x

Trajano E. \& Bichuette M. E., 2010 - Subterranean fishes of Brazil. In: Trajano E., Bichuette M. E. \& Kapoor B. G. (Eds.), Biology of Subterranean Fishes. Enfield: Science Publishers: 331-355.

Valente L. M. P., Bandarra N. M., FigueiredoSilva A. C., Cordeiro A. R., Simões R. M. \& Nunes M. L., 2007 - Influence of conjugated linoleic acid on growth, lipid composition and hepatic lipogenesis in juvenile European sea bass (Dicentrarchus labrax). Aquaculture, 267: 225-235. http://dx.doi.org/10.1016/j.aquaculture.2007.02.008

Vieira M. P., Vicose G. C., Gómez-Pinchetti J. L., Bilbao A., Fernandez-Palacios H. \& Izquierdo M. S., 2011 - Comparative performances of juvenile abalone (Haliotis tuberculata coccinea Reeve) fed enriched us non-enriched macroalgae: effect on growth and body composition. Aquaculture, 319: 423-429. http://dx.doi.org/10.1016/j.aquaculture.2011.07.024

Visentainer J. V., Souza N. E., Makoto M., Hayashi C. \& Franco M. R. B., 2005 - Influence of diets enriched with flaxseed oil on the a-linoleic, eicosapentaenoic and docosahexaenoic fatty acids in Nile tilapia (Oreochromis niloticus). Food Chemistry, 90: 557-560. http://dx.doi.org/10.1016/j.foodchem.2004.05.016

Visentainer J. V., Noffs M. D. A., Carvalho P. O., Almeida V. V., Oliveira C. C. \& Souza N. E., 2007 - Lipid content and fatty acid composition of 15 marine fish species from the southeast coast of Brazil. Journal of the American Oil Chemists' Society, 84: 543-547.

Wang J. T., Liu Y. J., Tian L. X., Mai K. S., Du Z. Y., Wang Y., Yang H. J., 2005 - Effect of dietary lipid level on growth performance, lipid deposition, hepatic lipogenesis in juvenile cobia(Rachycentroncanadum). Aquaculture, 249:439-447. http://dx.doi.org/10.1016/j.aquaculture.2005.04.038

Ward R. D.,ZemlakT.S., Innes B.H., LastP.R., HebertP.D.N., 2005-DNA barcodingAustralia's fish species. Philosophical Transactions of the Royal Society B, 360: 1847-1857. http://dx.doi.org/10.1098/rstb.2005.1716

Wilkens H., 2005 - Fish. In: Culver D. C. \& White W. B. (Eds.), Encyclopedia of Caves. London: Elsevier Academic: 241-251. 